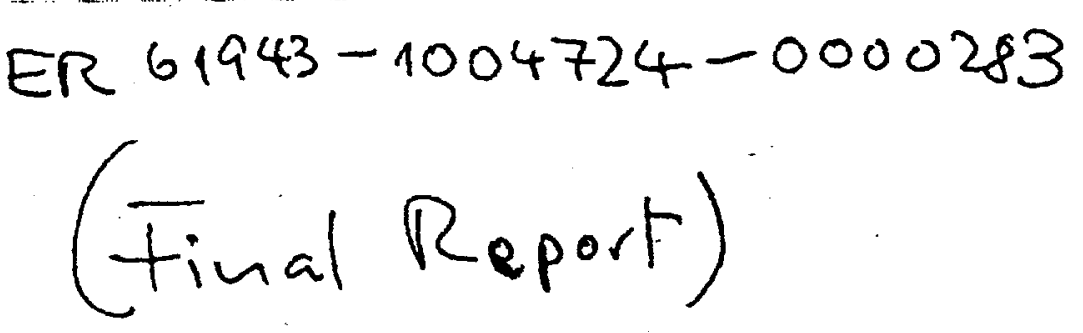

\title{
Development and Evaluation of a Global Version of the Miami Isopycnic-Coordinate Ocean Model
}

\author{
Bleck, Rainer \\ Miami, University of \\ Division of Meteorology \& Physical Otedhave no objection from a patent \\ Rosenstiel School of Marine \& Atmosphyctespont to the publication or \\ University of Miami \\ 4600 Rickenbacker Causeway \\ Rooth, Claes G.H. \\ Miami, University of \\ Division of Meteorology \& Physical Ocean \\ assemination of this material. \\ Rosenstiel School of Marine and Atmos. Sc. \\ University of Miami \\ 4600 Rickenbacker Causeway \\ Institution URL: http://www.rsmas.miami.edu \\ Projects URL: http://panoramix.rsmas.miami.edu/micom/
}

FY $1997 \$ 162 \mathrm{~K}$

FY $1996 \$ 156 \mathrm{~K}$

FY $1995 \$ 0 K$

DOE Program Manager: Patrick Crowley

KEYWORDS: global ocean modeling, isopycnic coordinates, climate dynamics

OBJECTIVE: To test the ability of the Miami Isopycnic-Coordinate Ocean Model (MICOM) to simulate the global ocean circulation, setting the stage for the model's incorporation into coupled global climate models.

OBJECTIVE: An existing basin-scale model will be expanded to global domain; suitable atmospheric forcing fields, including precipitation and river runoff, will be selected; the modeling of abyssal flow will be improved by incorporating compressibility and particularly thermobaric effects; a sea-ice model will be added; parameterization options will be explored for subgrid-scale deep convection; parallel coarse- and fine-mesh simulations will be carried out to investigate the impact of grid resolution; the sensitivity of the model's solution to magnitude of vertical (diapycnal) exchange coefficient will be studied; and long-term trends in meridional heat transport and water-mass properties in model solutions will be documented and interpreted.

RESULTS TO DATE: MICOM's seven time-dependent forcing functions characterizing the atmopheric state were generated for the global domain by reanalyzing COADS ship observations with emphasis on the high southern latitudes and by adaptation of global precipitation fields from NOAA's 


\section{DISCLAIMER}

This report was prepared as an account of work sponsored by an agency of the United States Government. Neither the United States Government nor any agency thereof, nor any of their employees, make any warranty, express or implied, or assumes any legal liability or responsibility for the accuracy, completeness, or usefulness of any information, apparatus, product, or process disciosed, or represents that its use would not infringe privately owned rights. Reference herein to any specific commercial product, process, or service by trade name, trademark. manufacturer, or otherwise does not necessarily constitute or imply its endorsement, recommendation, or favoring by the United States Government or any agency thereof. The views and opinions of authors expressed herein do not necessarily state or reflect those of the United States Government or any agency thereof. 


\section{DISCLAIMER}

\section{Portions of this document may be illegible in electronic image products. Images are produced from the best available original document.}


microwaver sounder. The algorithm for detraining mixed-layer water into discrete isopycnic layers was improved to cover situations where the mixed layer shoals because of freshwater input (ice melt) rather than warming. The scheme for converting diapycnal mixing processes into interlayer mass fluxes was replaced by a more efficient scheme. The temperature effect on compressibility was incorporated to correctly model the interaction of bottom water generated at high northern and southern latitudes. The Los Alamos sea-ice model was adapted for use in MTCOM and has been found to produce satisfactory results in 10-year test runs. A near-global coarse mesh version of MICOM [mesh size $1.4 \mathrm{deg} \times 1.4 \mathrm{deg}$ $\cos ($ lat.) ] was run for 600 years to study transients in the global thermohaline circulation and poleward heat fluxes; the model climate proved to be remarkably stable. An eddy-resolving version of MICOM [mesh size $0.225 \mathrm{deg} \times 0.225 \mathrm{deg} \times \cos (1$ at.) ], initialized with spun-up fields from the coarse-mesh run, was integrated for 11 years. A limited-area model, driven by time-varying lateral mass fluxes from the global run,was successfully tested on the Loop Current eddy-shedding process in the Gulf of Mexico. A 2-deg near-global version of MICOM (not yet including the polar grid and the ice model) was coupled to a T21 version of NCAR's CCM3. After 15 years of integration starting from Levitus climatology, the coupled system shows negligible drift as far as oceanic surface and subsurface properties are concerned. However, deficiencies in the geographic distribution of precipitation generated by the atmospheric model may affect the steadiness of the coupled system state.

DELIVERABLES: Bleck, R., S. Dean, M. O'Keefe, and A. Sawdey, 1995: A comparison of data-parallel and message- passing versions of the Miami Isopycnic Coordinate Ocean Model (MICOM). Parallel Computing, 1695-1720. Bleck, R., and S. Dean: Ocean Modeling Using Isopycnic Coordinates. Flyer distrib. at San Diego Supercomputing Conf., Los Alamos Natl. Lab., LALP-95-239, UC-902 \& 905, 2pp. Bleck, R., 1996: MICOM-based global modeling in the U.S. Internat. WOCE Newsletter, 23, Southampton, 31-33. Bleck, R., 1996: Miami begins global circulation modeling. ! WOCE Notes, 8(2), College Station, TX, 9-11. Bleck, R., S. Dean, and S. Sun, 1997: Global ocean simulations with an isopycnic coordinate model. In: Some New Directions in Science on Computers, eds. G. Bhanot, S. Chen and P. Seiden, World Scientific Pub., Singapore, in press, 21 pp. Sun, S., 1997: Compressibility effects in the Miami Isopycnic Coordinate Ocean Model. Ph.D. diss., Univ. of Miami.

COLLABORATIONS: This project is carried out in cooperation with Los Alamos National Laboratory. Principal Investigators on the LANL side are Dr. Len Margolin and Sumner Dean.

\section{OTHER:}

